\title{
DIFFERENT EXPRESSION PATTERNS OF ONCOGENES AND PROTO-ONCOGENES IN HEREDITARY AND CARCINOGEN-INDUCED TUMORS OF XIPHOPHORUS
}

\author{
Winfried MÄUELER ${ }^{1}$, Angelika SCHARTL and Manfred SCHARTL ${ }^{2}$ \\ Max-Planck-Institut für Biochemie, Am Klopferspitz 18 A, D-82152 Martinsried bei München, Germany.
}

\begin{abstract}
Hereditary melanoma in Xiphophorus hybrids carrying the melanoma-inducing Tu-Sd locus is caused by transcriptional activation of the $X$ mrk gene that resides at the Tu-Sd locus and encodes a novel member of receptor tyrosine kinases (RTK). In this study, a total of $\mathbf{2 7}$ hereditary melanomas from various hybrid genotypes harbouring 7 different Tu alleles were also found to over-express the corresponding $X$ mrk alleles. The level of over-expression correlated with the degree of malignancy of the melanoma. In addition, Xsrc expression was high in many malignant melanomas. Expression patterns and levels of the Xiphophorus EGF-receptor gene (Xerb B), the c-myc (Xmyc), and the PDGF (Xsis) gene(s) were not intriguing. Transcription of the ros gene(s) may be correlated to secondary events of melanoma progression. Expression patterns of Xfms, the $\mathbf{X i}$ phophorus CSF-I receptor homologue, can be explained by different contents of infiltrating macrophages in the tumors. In carcinogen-induced tumors including one melanoma no significant expression of the $X_{\text {mrk }}$ oncogene could be detected. Xsrc expression, however, was strikingly high. This indicates that activation of oncogenes other than Xmrk is instrumental in tumorigenesis of neoplasia of non-hereditary origin. ○ 1993 Wiley-Liss, Inc.
\end{abstract}

The Xiphophorus melanoma is uniquely suited to study primary events leading to neoplastic transformation of pigment cells as well as secondary and later steps in tumor formation and tumor progression responsible either for the maintenance of the neoplastic phenotype or for tumor malignancy. In addition to spontaneous (hereditary) melanoma formation, certain hybrids of Xiphophorus develop neoplasia of epithelial, mesenchymal and neuronal origin after appropriate treatment with carcinogens (e.g., MNU) (Anders et al., 1984; Schwab et al., 1978) offering the opportunity to study the processes responsible for the malignant phenotype on a comparative level in neoplasia of different etiology.

Spontaneous melanoma formation in certain hybrids of Xiphophorus has been attributed to the unscheduled activity of a cellular oncogene locus denominated $T u$ (Anders $e t$ al. 1984). We have cloned the melanoma-inducing gene from one specific allele $(S d)$ of the $T u$ locus (Wittbrodt et al., 1989). It encodes a novel trans-membrane receptor tyrosine kinase belonging to the EGF-receptor-multigene family (see Ullrich and Schlessinger, 1990) that is activated in melanoma (Wittbrodt $e t$ al., 1992). This gene is designated Xmrk. It is present in one copy as a constituent of the various X- or Y-chromosomal Tu alleles of Xiphophorus maculatus. Another copy of this gene does not map to the $T u$ locus and is present in all individuals of Xiphophorus. It obviously represents the corresponding $\mathrm{X} m r k$ proto-oncogene (INV) and is expressed as a single transcript of $5.8 \mathrm{~kb}$ at low levels in some epithelial tissues. Our preliminary studies indicated that expression of a certain X-chromosomal Xmrk oncogene allele encoded by the $\mathrm{Tu}$-Sd locus gives rise to a smaller transcript $(4.7 \mathrm{~kb})$ than does the proto-oncogene. Its abundance is high in malignant melanoma from pooled biopsy material. Three other $X$ - and Y-chromosomal alleles of the Xmrk oncogene have transcripts of similar size (Wittbrodt et al., 1989). It could be demonstrated that over-expression of the oncogenic Xmrk allele from the $T u-S d$ locus is due to transcriptional activation (Adam et al., 1991, 1993). This is the primary step leading to neoplastic transformation of pigment cells in Xiphophorus hybrids.

Nothing is known about the primary molecular processes leading to chemically or physically induced neoplasia of Xiphophorus hybrids. Several studies, mostly based on classical genetic analyses, led to the general hypothesis that activation of the $T u$ gene is also the primary cause of neoplastic transformation in carcinogen-induced neoplasia (Anders, 1989; Anders et al., 1984; Schwab et al., 1978). However, there is no molecular evidence for this until now. Little data are available comparing induced neoplasia with hereditary tumors at the molecular level. A few spontaneously developing nonmelanoma tumors of Xiphophorus hybrids were shown to express the proto-oncogene Xmrk but not the oncogene. In genotypes with a de-regulated $T u$ gene that develop melanoma following treatment with steroids the Xmrk oncogene transcript was detected (Zechel et al., 1992). Unfortunately, no carcinogen-induced somatic tumor was analyzed in this study. In an earlier study we showed that most of the carcinogeninduced neoplasia analyzed so far display similarly high or up to 5-fold higher levels of pp60 c-src-tyrosine-kinase activity (the gene product of the cellular src gene of Xiphophorus) as compared with spontaneously developing malignant melanoma. The activity of this tyrosine kinase was positively correlated with the malignancy but not with the etiology of the neoplasia (Schartl et al., 1985). The significance of the elevated tyrosine-kinase activities in all chemically and/or physically induced malignant neoplasia remains unclear, and was considered rather as a secondary phenomenon in tumor formation than as a primary step of neoplastic transformation (Schartl $e t$ al., 1985). In a study on different neoplastic lesions in Xiphophorus, it could be demonstrated that the features of intermediary metabolism depend on the tumor compartments (e.g., nodular or invasive areas), as well as the histiotype and the etiology of the tumor samples in a similar manner as it was observed for many mammalian and human neoplasia (Mäueler et al., 1987). Likewise these phenomena were explained as late secondary adaptions of the neoplastic cells during tumor progression.

The availability of molecular probes from the $T u$-encoded $\mathrm{X} m r k$ gene offers tools for a detailed analysis, comparing oncogene expression in single neoplastic lesions of spontaneously developing melanoma as well as single induced neoplasia of different origin in Xiphophorus. To verify that indeed the primary step leading to the formation of hereditary melanoma is over-expression of the oncogenic sex-chromosomal Xmrk alleles, we analyzed Xmrk expression in 27 single spontaneous

'Present address: Ruhr Universität Bochum, Abt. für Molekulare Humangenetik, Gebäude MA 5, D-44780 Bochum, Germany.

${ }^{2}$ To whom correspondence and reprint requests should be addressed, at Physiologische Chemie I, Theodor-Boveri-Institut für Biowissenschaften (Biozentrum) der Universität Würzburg, Am Hubland, D-97074 Würzburg, Germany.

Received: March 8, 1993 and in revised form May 28, 1993. 
hereditary melanomas caused by different X- and Y-chromosomal Tu loci. To investigate whether over-expression of Xmrk is also involved in the transformation processes of tumors induced by chemical carcinogens, 3 single neoplastic lesions including one melanoma induced by MNU were examined. To analyze a possible contribution of other receptor tyrosine kinase genes closely related to X $m r k$, the expression of Xerb B (the Xiphophorus homologue of the human $E G F$ receptor gene; Schartl et al., 1993) and of Xfms (homologue of the human CSF-1 receptor gene) was studied in the same neoplastic lesions. Other proto-oncogenes (Xsrc, Xras, Xmyc, Xsis) of possible significance for the neoplastic phenotype were also included.

\section{Experimental animals}

\section{MATERIAL AND METHODS}

The fish used in this study were bred under standard conditions (Kallman, 1975) in the aquarium of the Gene Center at the Max-Planck Institute for Biochemistry. Backcross hybrids (BC) of different genotypes of $X$. maculatus $(X$. mac.) bearing various sex-chromosomal X $m r k$ loci (distinguishable by specific small macro-melanophore spots on the body) using $X$. helleri $(X$. hell. $)$ as the recurrent parent were analyzed. $1, S d+1+$ : spotted dorsal, X-chromosomal Xmrk locus; $2, S d$ $a /+, a$ : albino locus; $S d$ carrying hybrids heterozygous for $a$ develop melanotic melanoma; $3, S d a / a, S d$-hybrids homozygous for $a$ develop amelanotic melanoma; $4, S d T$ : autosomal translocation of the X-chromosomal Xmrk locus. Of the offspring of all these back-crosses, $25 \%$ spontaneously develop benign and $25 \%$ malignant melanoma. When compared with malignant $S d$-melanoma the $S d$ a $/+$-melanoma were more malignant, while the $S d a / a$ and $S d T$ melanomas are more benign; 5, DrLi: dorsal red lineatus, mutation of the $\mathrm{X}$ chromosomal Xmrk-allele $\mathrm{Li} ; 6, N^{2}$ nigra extended, a mutation of the Y-chromosomal Xmrk-locus nigra; 7, Sb: spotted belly, Y-chromosomal Xmrk-locus; 8, $A r S r^{\prime}$ : anal red, striped, Ychromosomal Xmrk allele. The founder fish for this strain had been X-irradiated by A. Anders (at least 20 back-cross generations ago). Of the back-cross hybrids, 1 to $5 \%$ develop malignant melanoma spontaneously; $9, \mathrm{Sr}^{\prime \prime}$ : mutation of $\mathrm{Sr} ; 10$, $L i$, lineatus, $\mathrm{X}$-chromosomal locus from $X$. variatus. These hybrids were used for carcinogen treatment; up to $20 \%$ develop, besides benign melanoma, neoplasia of epithelial, mesenchymal and neural origin. The induced neoplasia were highly malignant and killed the fish within 2 to 4 months (for a detailed description of the crossing procedures, the genotypes and the phenotypes, see Anders and Anders, 1978; Anders et al., 1973, 1984; Schartl et al., 1985). Tumors were surgically removed, immediately frozen and stored in liquid nitrogen until preparation of RNA.

\section{Cell lines}

Cell lines were cultured under the conditions described (Mäueler et al., 1988a). After reaching confluence, cells were harvested and used for preparation of RNA.

\section{Treatment of fish and tumor diagnosis}

$N$-methyl- $N$-nitrosurea (MNU) was administrated by exposing tumor-free $X$. var. $L i \times X$. hell. back-cross hybrids to a $10^{-3}$ $M$ solution of the carcinogen 4 times for $1 \mathrm{hr}$ at 2 -week intervals. All tumors were classified according to data obtained by gross inspection of localization and growth rate and by histopathological analysis. For light microscopy, all specimens were fixed in Bouin's solution. Excess picric acid was eluted in $70 \%$ ethanol. The fixed specimens were dehydrated and embedded in paraffin. Sections $(5 \mu \mathrm{m})$ were cut with a Leitz base sledge microtome and stained according to classical histopathological staining methods used for vertebrate tumor diagnosis.

\section{Hybridization probes and labelling}

All probes used for hybridization were separated from vector sequences and highly GC-rich sequences of the insert after appropriate restriction-enzyme digestion and low-meltingpoint agarose-gel electrophoresis. Probes used for nicktranslation were further purified through NACS columns (BRL, Eggenstein, Germany). The following heterologous probes were used: (i) 2 internal 400-bp PstI fragments of the $\mathrm{v}$-fms-gene 5' of the kinase domain (ATCC, Rockville, MD); (ii) 700-bp BglII/Pst I fragment D of pHB-II (Ellis et al., 1980) of the v-ras gene of Harvey murine sarcoma virus; (iii) the 1.5-kb EcoRI/PstI fragment of the trout c-myc clone C-181 (Tmyc), containing sequences homologous to exon 2 and 3 of chicken c-myc (VanBeneden et al., 1986). The Xiphophorusspecific probes used were: (iv) Xmrk cDNA clone 3-2 (Wittbrodt et al., 1989) encompassing the extracellular and transmembrane domains of Xmrk; (v) 1.6-kb genomic Xerb B clone p38-1 (Schartl et al., 1993) containing 2 exons; the coding region of these clones share $82 \%$ homology to the v-erb $B$ gene and $83 \%$ homology to the human $H E R-1$ gene; (vi) 300-bp BamHI/BglII Xsis fragment (gift from U. Schlehenbecker); (vii) 1.3-kb BamHI fragment of the Xsrc cDNA (clone 726) containing exons 1-11 (data not shown). Nick-translations of the fms, ras and Tmyc probes were performed as described (Sambrook et al., 1988), using a kit from Amersham Buchler (Braunschweig, Germany). All other probes were labelled by random priming according to the protocol of Feinberg and Vogelstein (1984). Labelling was done using ${ }^{32} \mathrm{P}$-labelled nucleotides. Random-primed probes on the one hand and nick-translated probes on the other hand were labelled to comparable specific activities.

\section{Northern blot analysis}

Total cellular RNA was isolated by the $\mathrm{LiCl}$ procedure (Le Meur et al., 1981) using ultraturrax N8 (Janke and Kunkel, Staufen, Germany) for homogenization. Total RNA $(20 \mu \mathrm{g})$ was denatured with formamide/formaldehyde and electrophoresed in $1.2 \%$ agarose gels containing $2.2 \mathrm{M}$ formaldehyde (Lehrach et al., 1977). For size calibration, an RNA-ladder (BRL, Bethesda) was included. RNA was electroblotted to Gene screen or Hybond $N$ membranes according to the protocol of the suppliers (Amersham Buchler). For exact quantitation of the RNA amount present on the hybridization membrane, each filter was stained with methylene blue (Khandjian, 1986) and the relative amounts of RNA were determined densitometrically. Filters were hybridized with $10^{7} \mathrm{dpm} / \mathrm{ml}$ of the labelled probes. The same filters were used for the different probes after stripping oft the hybridization signals. Hybridization with homologous probes was carried out with $50 \%$ formamide, with heterologous probes with $40 \%$ formamide, both at $42^{\circ} \mathrm{C}$. Membranes were washed at different temperatures in SSC solutions containing $1 \%$ SDS (2 washes for $5 \mathrm{~min}$ at room temperature, followed by 2 washes for $45 \mathrm{~min}$ at the final washing temperature) and then exposed to Kodak X-OMAT AR $15 \mathrm{X}$-ray films between 2 intensifying screens. The exact washing conditions are indicated in the figure legends. Exposure times were selected to correct for differences in the specific activities of the probes.

\section{RESULTS}

The tumors used in this study were of different etiology, namely hereditary or carcinogen-induced. All were melanomas and fibrosarcomas. All melanomas examined were of cutaneous origin (Fig. 1a,b) and could be classified as benign or malignant, melanotic or amelanotic, as described for $\mathrm{Xi}$ - 

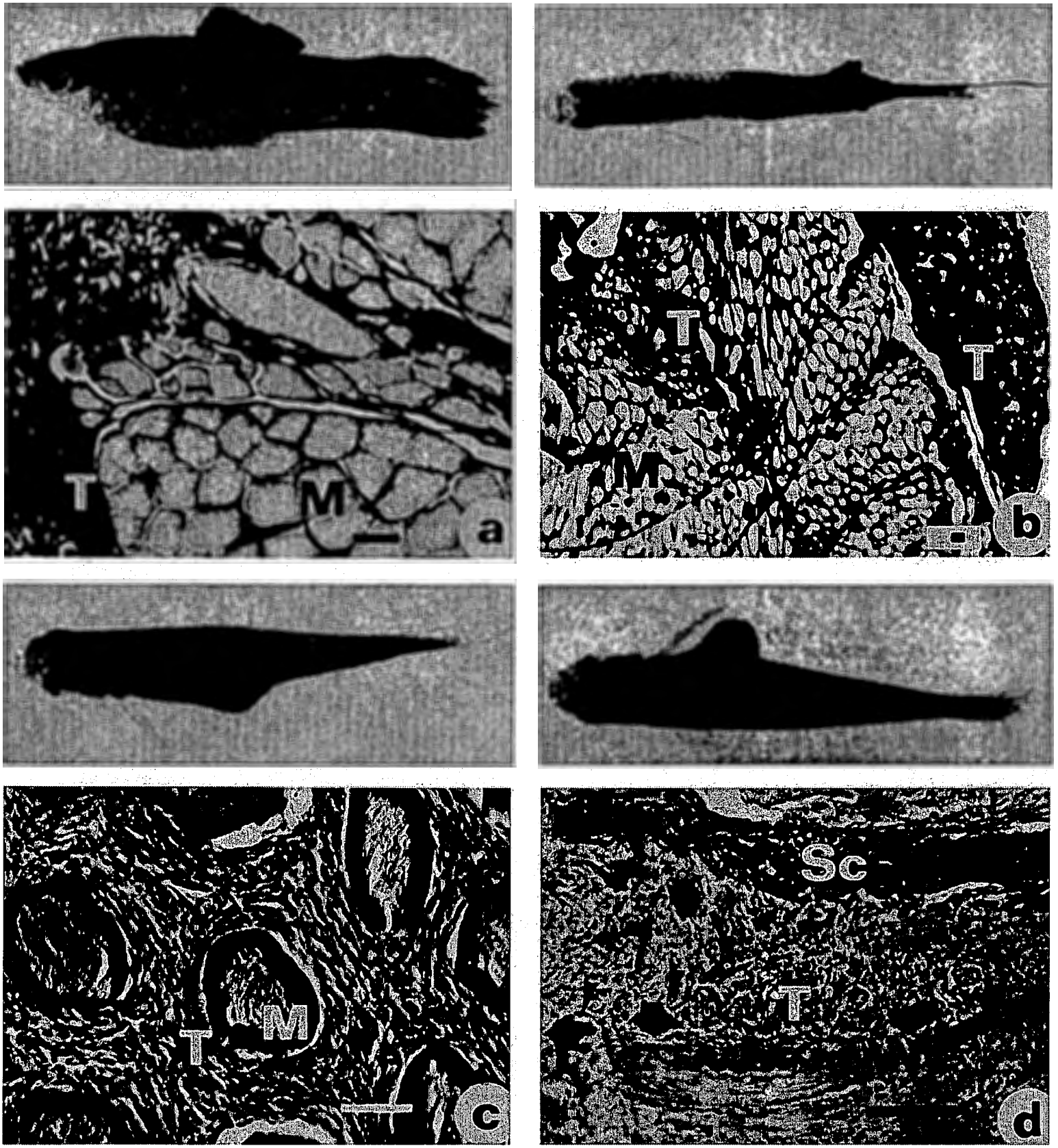

FigURE 1 - Habitus and histological overview of the tumors. (a) Spontaneous hereditary melanoma in the dorsal fin, the dorsal and ventral posterior part of the trunk and tail fin of a back-cross hybrid $X . m a c \mathrm{Sd} / X$.hell. $\mathrm{BC}_{\mathrm{t}}$. Transversal section showing the melanoma invading the muscles (HE stain). (b) Induced melanoma in the upper posterior part of the trunk of a back-cross hybrid X.var.Li/X.hell. BC Transversal section displaying the melanoma invading the muscles (HE stain). (c) Induced fibrosarcoma on the left body side underneath the dorsal fin of a back-cross hybrid X.var. Li/X.hell. $\mathrm{BC}_{\mathrm{n}}$. Transversal section demonstrating the spindle-shaped tumor cells invading between the muscle bundles (SA stain). (d) Induced pigmented fibrosarcoma on the right side of the body behind the pectora fin of a back-cross hybrid X.var. Li/X.hell $\mathrm{BC}_{\mathrm{n}}$. Parasagital section illustrating the tumor cells destroying the skeletal muscles, dispersed pigment cells (arrows) and melanin sedimentation (arrow heads). The interspersed pigment cells result in a dark coloring of the exophytic compartment of the tumor (HE stain). M, muscle; Sc, stratum compactum; T, tumor; bars represent $50 \mu \mathrm{m}$.

phophorus hybrids (Vielkind et al, 1971; Riehl et al., 1985), of either early or late onset (Wakamatsu et al., 1984). All tumors were well vascularized. The fibrosarcomas (Fig. $1 c, d$ ) originated in the soft tissue of the trunk. They showed fast, nodular and infiltrative growth. In exophytic tumors the transformed cells penetrated the stratum compactum. Most tumor cells were poorly differentiated and organized in bundles or showed typical whirls after destruction of muscle bundles. Vascularization was only poorly developed. All fibrosarcomas were classified as malignant. 
Expression in spontaneously developing melanoma caused by the $X$-chromosomal Tu-Sd Xmrk locus

In fish of this genotype the benign or malignant state of the mclanoma is genetically controlled by the presence or absence of $R$ (regulatory genc, controlling expression of $T u$ ), thus making it possible to establish correlations of expression level with tumor malignancy. All melanoma analyzed in this study contained, in addition to the 5.8-kb transcript cncoded by the proto-oncogenic INV locus (Fig. 2; Xmrk, 16) the major 4.7-kb transcript encoded by the oncogenic Tu-Sd locus of Xmrk. The amount of the $I N V$ transcript was low. There was some minor variation in cxpression which followed the expression pattern of the oncogene transcript. The oncogenc transcript was present in all single or pooled malignant mclanomas at very high levels. The absolute amounts varied considerably bctween different melanomas; comparison of transcript abundance in $S d$ melanomas of different malignancy (Fig. 2, 1 to 13; Fig. 3, 1 to 3 ) revealed a positive corrclation with the malignant phenotype of the melanoma. A melanoma cell line (PSM) contained the highest amounts of transcripts. In RNA of the immortalized embryonic ccll line, A2, only transcripts of the INV locus wcre detectable at low levels.

A single 5.0-kb Xerb B transcript was detected in most of the melanoma mRNA at very low levels (Fig. 2). No obvious corrclation betwecn expression levels of Xerb B and tumor malignancy was obscrved.

For Xfms a single transcript of approximatcly $6.0 \mathrm{~kb}$ was observed in most of the malignant melanoma of the $T u-S d$ genotype (Fig. 2). The level of expression ranges from relativcly high to only barcly detectable, indicating no obvious correlation of the expression of Xfms with tumor malignancy or cxpression of the Xmrk genc. Whereas in several malignant lesions a clear expression was found, no expression of X $\mathrm{fms}$ was detectable in the melanoma cell line and the embryonal A2 cells.

Hybridization with the Xsrc cDNA probe revealed a major (Xsrc1, 3.7 kb) and a minor Xsrc transcript (Xsrc2, 3.4 kb) (Fig. 2). The level of expression of Xsrcl in most malignant melanomas was high. However, the correlation with malignancy is less obvious than for Xmrk. The Xsrc2 transcript was detected in 7 out of 13 melanomas. Interestingly, the melanoma cell line PSM contained only the Xsrc2 transcript, and the cmbryo-derived cell line A2 only the Xsrcl transcript.

Threc Xras-transcripts (Xras1, 3.4 kb; Xras2, 3.0 kb; Xras3, $1.8 \mathrm{~kb}$; Fig. 2) can be detected in Xiphophorus. Xras 1 and 3 were present at barcly detectable levels in the TH-Sd melanoma. The major transcript Xras 2 was found in 5 of 13 mclanomas in relatively high amounts. Hybridization with the Xsis probe revealed very low amounts of a 3.4-kb Xsis transcript. Only the non-transformed A2 cells contained slightly higher amounts of the 3.4-kb and a second Xsis-transcript (data not shown). With few exceptions, only basal expression of Xmyc was seen in the mclanomas. Multiple transcripts werc, however, readily detectable in both cell lines (Fig. 2).

\section{Expression in spontaneously developing melanoma caused by} other sex-chromosomal X mrk loci

To investigate the rolc of Xmrk in spontancously devcloping melanoma caused by Xinrk alleles encoded by other Tu loci than $T u-S d$ (marked by other pigment cell patterns and by different pathological features of the tumors), wc analyzed RNA of single or pooled melanoma of such fish. Hybrids containing cither the X-chromosomal Tu-DrLi or the Y-chromosomal Tu-Sr". Tu-Sb, or Tu-N $\mathrm{N}^{2}$ oncogenic alleles of Xmrk spontancously devclop highly malignant, progressively growing melanotic melanoma with a frequency of approximately $15 \%$ during senescence. These melanoma develop from superficially spreading non-invasive melanoma which occur in all fish that carry the corresponding Xmrk alleles. They are classified as late-onset hereditary melanomas. This is in contrast to Tu-Sd mclanomas, which develop early in life.

RNA from different malignant melanomas of such hybrids containcd, in addition to a low level of the $5.8-\mathrm{kb} I N V-\mathrm{X} m r k$ proto-oncogene transcript, relativcly high amounts of the 4.7-kb transcript (Fig. 3). As in Sd melanomas, the low level of the INV transcript showed some variation that followed the pattern of the oncogene transcript. For the oncogene transcript, in contrast to the expression from the $S d$ locus, transcript levels of the DrLi locus were found to be more variable between diffcrent malignant melanomas. RNA of the highly malignant melanomas caused by Y-chromosomal oncogenic loci $\left(S r^{\prime \prime}, S b, N^{2}\right)$ uniformly contained amounts of the 4.7-kb transcript similar to or higher than RNA from melanomas caused by the $S d$ locus. RNA of 2 of these melanomas $(9$, 12) contained in addition a Xmrk transcript of very large size. One genotype was included that carrics a $T u$ allcle of low penetrance $\left(\mathrm{Tu}-\mathrm{ArSr} \mathrm{r}^{\prime}\right)$. In melanomas of such fish, the corresponding Xmrk allele was also found to be over-expressed (Fig. 4).

Using the same RNAs for hybridization, very low expression of Xerb B (Fig. 3) and of Xmyc was observed. In all melanomas the Xfms transcript was detected (Fig. 3). Again, as observed for the $T u$-Sd melanomas, the levels of transcript ranged from relatively high to only barely detcctable.

Hybridization with the Xsrc cDNA revealed both Xsrc transcripts at variable, but sometimes very high lcvels (Fig. 3 ). $\mathrm{Xsrc} 2$ transcripts werc detected only in those melanomas showing the highest levels of Xsrcl transcripts. For Xras only the major Xras2 transcripts werc detected at varying levels. Expression of Xsis was observed in RNA of mclanomas causcd by Y-chromosomal Xmrk loci, but at relatively low levels (data not shown)

\section{Expression in chemically induced neoplasms of Xiphophorus}

To investigate whether the activity of the different scxchromosomal Xmrk loci is restricted to spontaneously devcloping (hereditary) melanomas, RNA of chemically induced malignant neoplastic lesions of Xiphophorus was analyzed. In 2 fibrosarcomas (Fig. 4a), no transcripts of Xmrk werc detected. RNA of an induced melanoma contained low amounts of a very large transcript (approximately $9 \mathrm{~kb}$ ). Such large-sizc transcripts were also observed in several hereditary mclanomas (Fig. 2, 9 to 11; Fig. 3, 9 to 13) and may represent a hnRNA. The mature transcripts from the proto-oncogene (5.8 $\mathrm{kb})$ and the oncogene $(4.7 \mathrm{~kb})$ were not detected in induced tumors.

No transcripts of Xerb B or Xfms werc observed. With the Xsrc cDNA probe (Fig. 4b) very high amounts of Xsrc I were found in both fibrosarcomas, while the melanoma RNA contains only low amounts. Xsrc 2 was barcly detectable. Xras 2 transcripts were found to be present in all 3 induced neoplasms at relatively low levels and comparable to that observed in RNA of most of the hereditary mclanomas. Xras 1 and 3 transcripts were again not observable. The level of Xsis expression was low, but slightly higher than observed in hereditary mclanomas (data not shown). Multiple $\mathrm{X} m y c$ transcripts were found in the induced ncoplasms at low levels. Both fibrosarcomas contain several small transcripts (approx. 1.6 $\mathrm{kb})$ which wcre not present in the induced melanomas or in most of the spontancously dcvcloping melanomas.

\section{DISCUSSION}

In this study we have shown that 27 hereditary malignant melanomas originating from 7 different $\mathrm{X}$ - and Y-chromosomal alleles of $T u$ over-express the $4.7-\mathrm{kb}$ X $m r k$ transcript. The abundance of this transcript correlated with the malignancy of the melanoma. For the Tu-Sd allele of Xmrk, we have 


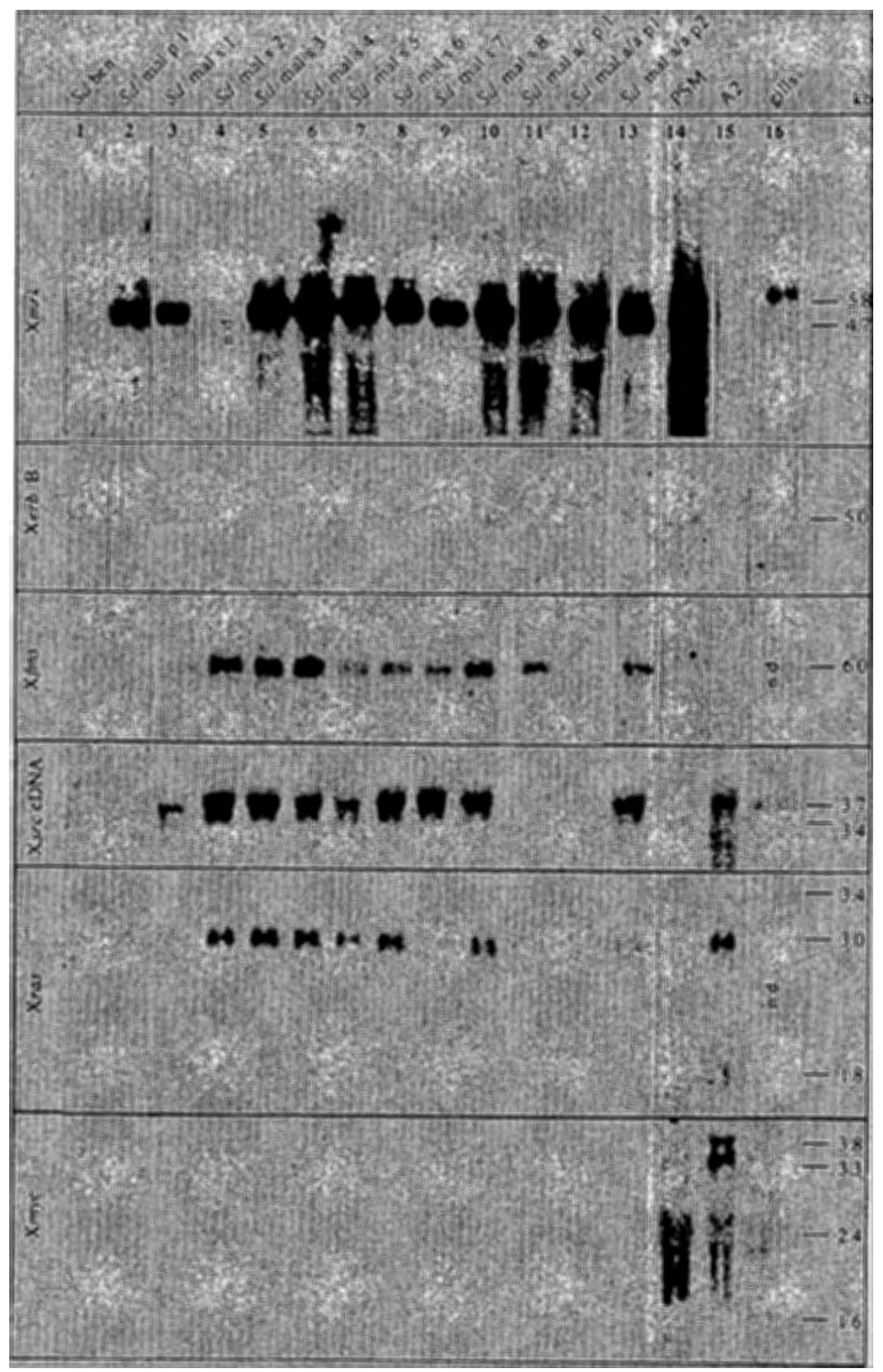

Figure 2 - Expression of Xmrk, Xerb B, Xfms, Xsrc, Xras and Xmyc in RNA of single and pooled Tu-Sd melanoma of Xiphophorus; 20 $\mu g$ of total RNA of each sample were hybridized with the Xmrk, Xerb B v-fms, v-ras and Tmyc-probe as described in "Material and Methods". Lane 1, benign (ben) melanotic melanoma; lanes 2 to 10, highly malignant (mal) melanotic melanoma; lane 11, highly malignant melanotic melanoma from fish heterozygous for $a$ (albino); lanes 12 and 13, malignant amelanotic melanoma from fish homozygous for $a$ (albino); lane 14, PSM melanoma cell line; lane 15, A2 embryonal cell line; lane 16, X.maculatus pills; p, pooled biopsy material; s, individual melanoma; n.d., not done. Final washings were: for $\mathrm{Xmrk} 55^{\circ} \mathrm{C}, 0.5 \times \mathrm{SSC}(1,2,11) ; 60^{\circ} \mathrm{C}, 0.1 \times \mathrm{SSC}(3-10$ 12-14); for Xerb B, $50^{\circ} \mathrm{C}, 1 \times \mathrm{SSC}$; for v-fms, $55^{\circ} \mathrm{C}, 0.5 \times \mathrm{SSC}$; for Xsrc cDNA, $50^{\circ} \mathrm{C}, 1 \times \mathrm{SSC}$; for $\mathrm{Xras}, 50^{\circ} \mathrm{C}, 2 \times \mathrm{SSC}$; for $\mathrm{Xmyc}, 45^{\circ} \mathrm{C}$, $2 \times \operatorname{SSC}(14,15) ; 50^{\circ} \mathrm{C}, 2 \times \operatorname{SSC}(1-12,16)$. 


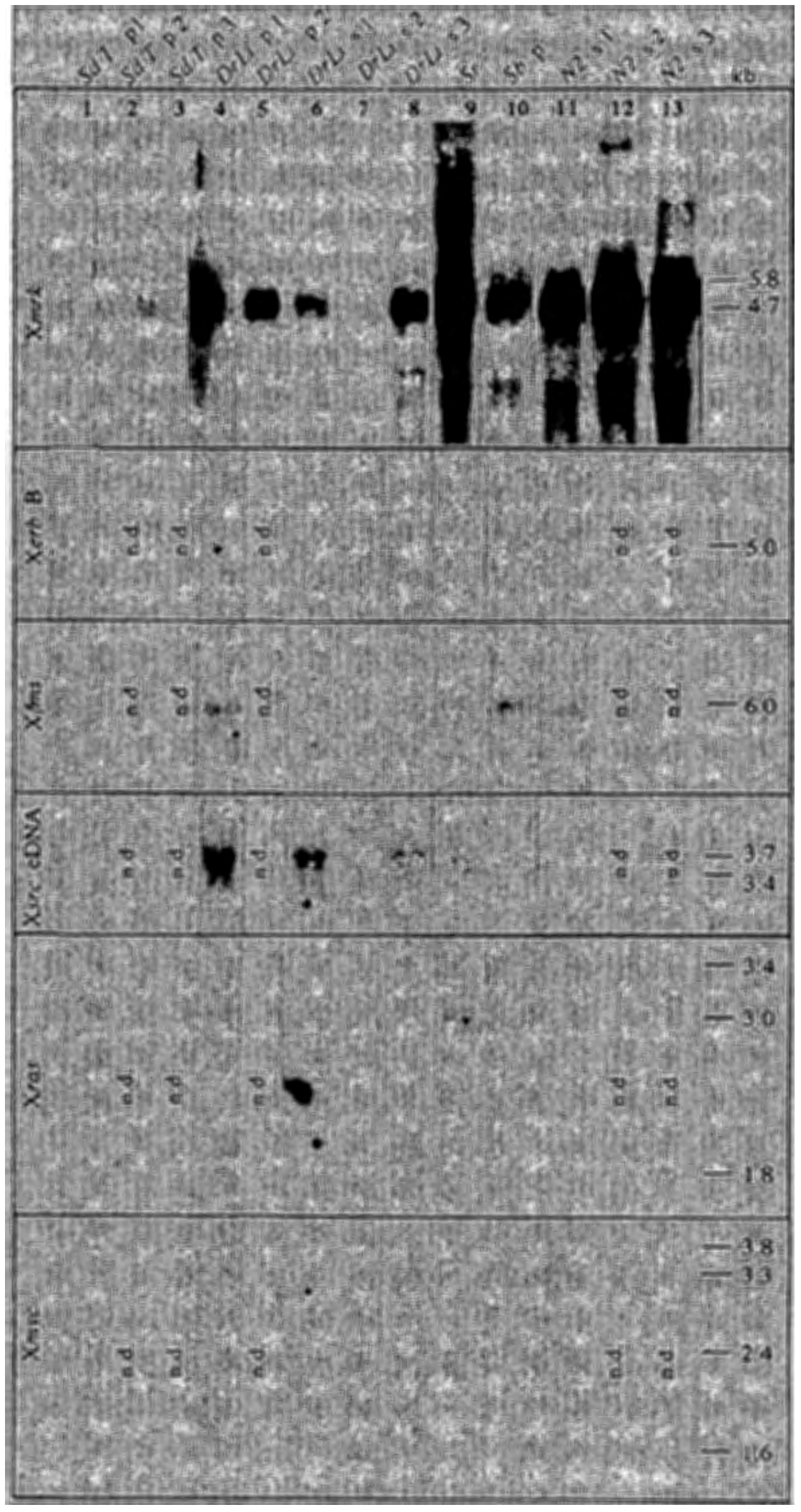

FiguRE 3 - Expression of Xmrk, Xerb B, Xfms, Xsrc, Xras and Xmyc in RNA of single and pooled neoplasia of Xiphophorus caused by different Tu alleles; $20 \mu \mathrm{g}$ of total RNA of each sample were hybridized as indicated in Figure 2. Lanes 1 to 3, benign melanotic $S d T$ melanoma; lanes 4 to 8, malignant melanotic $D r L i$ melanoma; lane 9, highly malignant melanotic $S r^{\prime \prime}$ melanoma; lane 10 , highly malignant melanotic $S b$ melanoma; lanes 11 to 13 , highly malignant melanotic $N^{2}$ melanoma. p, pooled biopsy material; $s$, individual melanoma; $\mathrm{d}$, not done. Final washes were: for Xmrk, $50^{\circ} \mathrm{C}, 1 \times \operatorname{SSC}(5-8) ; 55^{\circ} \mathrm{C}, 0.5 \times \operatorname{SSC}(2,10,13) ; 60^{\circ} \mathrm{C}, 0.5 \times \operatorname{SSC}(1,9,12)$ $60^{\circ} \mathrm{C}, 0.1 \times \operatorname{SSC}(3,4,11)$; for Xerb B, $50^{\circ} \mathrm{C}, 1 \times \mathrm{SSC}$; for Xfms, $55^{\circ} \mathrm{C}, 0.5 \times \mathrm{SSC}$; for Xsrc cDNA, $50^{\circ} \mathrm{C}, 1 \times \mathrm{SSC}$; for Xras, $50^{\circ} \mathrm{C}, 2 \times \mathrm{SSC}$ for $\mathrm{X}_{m y c}, 45^{\circ} \mathrm{C}, 2 \times \operatorname{SSC}(2-8) 50^{\circ} \mathrm{C}, 2 \times \operatorname{SSC}(1,9-11)$. 


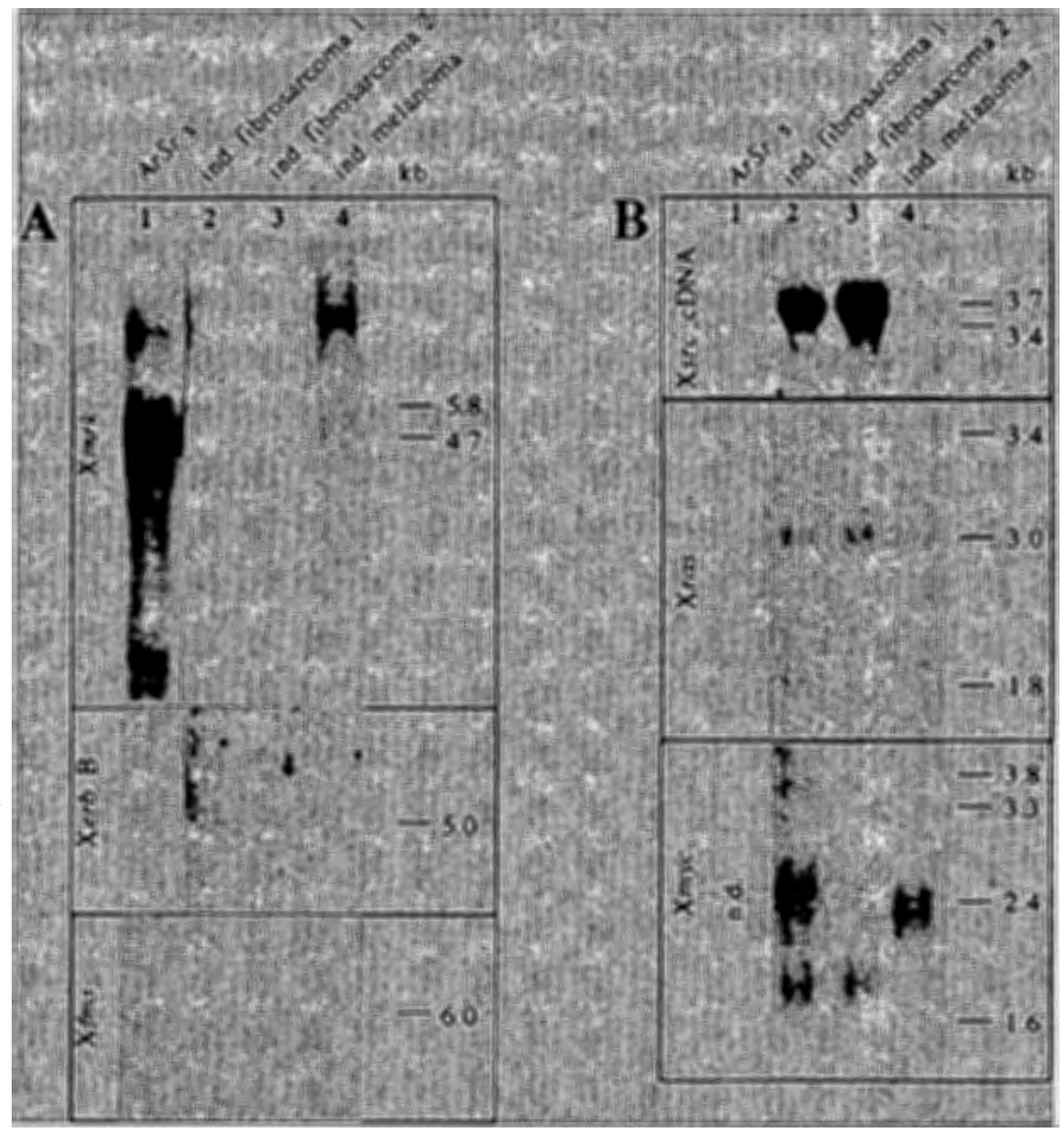

FTGURE 4 - Expression of (a) Xmrk, Xerb B, Xfms and (b) Xsrc, Xras, Xmyc in RNA of single neoplasm of Xiphophorus; $20 \mu \mathrm{g}$ of total RNA of each sample were hybridized as indicated in Figure 2. Lane 1, spontaneously developing highly malignant melanotic $S r$ melanoma; lanes 2-4, highly malignant chemically induced individual neoplasm; n.d., not done. Final washes were: for $\mathrm{Xmrk} 60^{\circ} \mathrm{C}, 0.1 \times$ SSC (1); $60^{\circ} \mathrm{C}, 0.5 \times \operatorname{SSC}(2-4)$; for Xerb B, $50^{\circ} \mathrm{C}, 1 \times \mathrm{SSC}$; for Xfms, $55^{\circ} \mathrm{C}, 0.5 \times \mathrm{SSC}$; for Xsrc cDNA, $50^{\circ} \mathrm{C} 1 \times \mathrm{SSC}(2-4)$; all others $50^{\circ} \mathrm{C}, 1 \times \mathrm{SSC}$.

previously shown that its transcription is controlled by a $5^{\prime}$ upstream region different from that of the corresponding proto-oncogene (Adam et al., 1991). The new promoter was acquired during evolution by non-homologous recombination from a hitherto uncharacterized locus (Adam et al., 1993). Over-expression of other Xmrk alleles from other Tu loci in malignant melanoma of the corresponding hybrids, as shown in this study, indicates similar genomic organization and mode of oncogene activation. The acquisition of the oncogene promoter would thus date back to an early stage in the evolution of these fish, since some of the different Xmrk alleles investigated are derived from feral populations that have been zoogeographically separated for a long time.

The level of over-expression in malignant melanomas was found to be variable to some degree. In general, a positive correlation between over-expression of X $\mathrm{mrk}$ and degree of malignancy could be established. Moreover, since undissected melanomas were used in this study, it is possible that the minor variations are due to differences in distinct tumor compartments (e.g., well-vascularized exophytic- and/or rapidly progressing invasive compartments) of the individual melanoma As shown earlier (Mäueler et al., 1987), such compartments are characterized by differences in intermediary metabolism.
In contrast to the quantitative differences of the Xmrk oncogene transcripts in benign and in highly malignant melanomas, the expression of the proto-oncogene remains more or less on a basal level. In some tumors with very high oncogenetranscript levels, a 2- to 3-fold increase in the proto-oncogene mRNA is apparent. This may be explained by a general activation of transcription in these progressive tumors. A similar phenomenon has been observed for expression of the proto-oncogenes $\mathrm{Xsrc}, \mathrm{X} r a s$ and $\mathrm{X} m y c$. This is consistent with earlier findings in vitro (Mäueler et al., 1988a).

Some of the hereditary melanomas contain additional highmolecular-weight transcripts of Xmrk. These melanomas were classified as extremely malignant, and displayed the highest amounts of Xmrk transcripts. It is possible that these highmolecular-weight transcripts are precursor RNA that is incompletely spliced, probably due to a high transcription rate of the gene. Additional transcripts of abnormal size of an overexpressed human $E G F-R$ gene were also observed in glioblastomas (Libermann et al., 1985), as well as in cells derived from squamous-cell carcinomas (Yamamoto et al., 1986) and mammary-carcinoma cells (King et al., 1985; Filmus et al., 1985). Our data, however, do not support the hypothesis of Zechel $e t$ al. (1992) that such a large Xmrk-oncogene transcript is 
mRNA specific for the $T u-L i$ locus of $X$. variatus, because we also detect it besides the maturc message in melanomas of other genotypes.

In contrast to the situation in hereditary melanomas, mature transcripts of the $I N V$ or of the oncogenic Xmrk locus were not detected in any of the induced tumors. Only the induced melanomas contained a probably unspliced high-molecularweight Xmrk transcript. Earlier hypotheses assumed that onc and the same locus, namcly $T u$, was responsible for the devclopment of hereditary mclanomas as well as for the neoplastic transformation of cells after trcatment with chemical carcinogens (Anders, 1989; Anders et al., 1984; Schwab et al., 1978), or cven for tumors of every possible etiology (Zechc et al., 1992). Our data clcarly indicatc that all hereditary melanomas are caused by over-cxpression of oncogene alleles of Xmrk. Hence, chemical induction of neoplasia including melanoma in Xiphophorus is mediated by activation of other as yct unidentified proto-oncogenes. In view of the clear dichotomy of melanomagenesis in Xiphophorus on the molecular level, it is tempting to discuss whether such dichotomy is also secn in human hereditary tumors and their spontancous counterparts. We are not aware of any molecular data on this problem. However, there are some clues that point in this direction. For example, in human spontaneous melanoma a plethora of different activated genes, including ras genes, growth-factor genes, and p53 have been found (Albino, 1992) At lcast 3 different chromosomal regions have been implicated in the formation of familial melanoma (for review, sce Travis, 1992) none of which rclatcs obviously to the activated genes found in spontaneous melanoma. Similarly, for familial Wilms tumor 3 different loci have been identificd, cach of which can provide as a tumor-suppressor gene the predisposition to develop this cancer (Francke, 1990). There might be multiplc ways on the molecular level to create tumor phenotypes that are otherwise indistinguishable.

In order to study the function of gencs closely related to $\mathrm{X} m r k$ in hereditary melanomas and induced neoplasia, we measured the expression of Xerb B and of Xfms. The expression of the Xerb B gene was found to be very low in all tumors analyzed. A corrclation with tumor malignancy or expression of Xmrk was not apparent. Obviously, expression of Xerb B is of subordinate importance for these tumors, and is not co-regulated with Xmrk. Such a co-regulation of closely related members of a gene family, however, has been observed for Xyes, Xfyn and Xsrc (Hannig et al., 1991). Most of the hereditary melanomas containcd relatively high amounts of the Xfms transcript. The level of expression is not correlated with the malignancy of the melanoma or with the expression of $\mathrm{X} m r k$. In addition, nonc of the induced highly malignant neoplasms contained detectable amounts of Xfms transcripts. In mammals, $C S F-1 R$ is onc of the factors playing an important rolc during maturation and growth activation of macrophages (Sariban et al., 1985; Sherr, 1988; Sherr et al., 1985). Macrophages are present at places that give rise to infection. Necrotic compartments of fish melanomas are often infected by fungi or bactcria which produce an inflammatory response. Thereforc an explanation for the variability of $\mathrm{Xfms}$ expression in the melanomas could be the presence of differen amounts of macrophages expressing the Xfms gene. This observation is confirmed by the finding that the melanoma cell line PSM does not express the Xfins genc. The expression data on Xmyc, Xras and Xsis were not of special intcrest, they were rather low, and did not correlate with tumor malignancy or ctiological origin. Altcred expression of these genes, thercfore, does not appear to be a relcvant factor in tumorigenesis in Xiphophorus.

Expression studies with the Xiphophorus-specific src cDNA probe revcalcd 2 different transcripts. Both transcripts were also detected in normal brain and eyes, thus none is specific for tumor cells (Mäueler et al., 1988b; Raulf et al., 1989). The level of expression in most of the neoplasms is higher than in any normal tissue. Earlier experiments revealed approximately 10 -fold increased pp60-src activity cncoded by the Xsrc2 transcript of the PSM cells in comparison with that from the Xsrc 1 transcript of A2 cells (Mäueler et al., 1988a). Elevated pp60-sre kinase activity has been observed in correlation with malignancy in hereditary melanoma and in carcinogeninduced tumors of mesenchymal origin (Schartl et al., 1985). Our RNA cxpression data are in perfect agreement with these earlier finding. The Xsrc gene has been shown to be localized on an autosome and is therefore independent of the sexchromosomal Tu locus encoding Xmrk. As the latter is the primary melanoma-inducing gene, activation of Xsrc is a downstream cvent in melanomagenesis. Its association with malignancy of hereditary melanomas and also the activation in several carcinogen-induced tumors of different histiotypes, including fibrosarcoma and mclanoma, lead to the assumption that $\mathrm{X}$ src is an important and necessary factor in tumor progression.

In summary, we have demonstrated that there exist at least 2 molecular mechanisms leading to malignant melanomas in Xiphophorus: Xmrk over-cxpression leading to hereditary melanomas, and the activation of unknown proto-oncogenes causing induced melanomas. The Xsrc gene appears as an important factor downstream of the primary event, possibly necessary for tumor progression. Further experiments, screening a much larger population of different induced neoplasms of different histiotypes, for transcripts of as many protooncogenes as possible, are necded to identify more of the factors involved in the multistep process of carcinogenesis, and to distinguish phenomena that are common to different cancer cells in vivo from those that are specific to the histiotype.

\section{ACKNOWLEDGEMENTS}

We thank Dr. C.R. Schmidt for carcinogen treatment of the fish, Mrs. S. Martinus for technical assistance in tumor histology, and Mrs. S. Becker for documentation of the RNA data. This study was supported by grants to M.S. supplied by the Bundesministerium für Forschung und Technologic, Schwerpunkt "Grundlagen und Anwendungen der Gentechnologie" and by the Deutsche Forschungsgemeinschaft, Schwerpunkt "Tumorzytogenetik".

\section{REFERENCES}

ADAM, D., Dimitrijevic, N. and SChaRti, M., Tumor suppression in Xiphophorus by an accidentally acquired promoter. Science, 259, 816-819 (1993).

ADAM, D., MÄLELER, W. and SCHARTL, M., Transcriptional activation of the melanoma-inducing Xmrk oncogene in Xiphophorus. Oncogene, 6, 73-80 (1991).

ALBINO, A.P., The role of oncogenes and growth factors in progressive melanoma-gencsis. Pigment Cell Res., Suppl. 2, 199-218 (1992).

ANDERS, $\Lambda$ and ANDERS, F., Etiology of cancer as studied in the platyfish swordtail system. Biochim. biophys. Acta, 516, 61-95 (1978). ANDERs, A., ANDERs, F. and Kl.INKE, K., Regulation of gene expres sion in the Gordon-Kosswig melanoma system. I. The distribution of controlling genes in the genome of xiphophorin fish Platypoecilus variatus. II. The arrangement of the chromatophore-determining loci and regulating elements in the sex chromosomes of xiphophorin fish Platypoecilus maculatus and Platypoecilus variatus. In: H.J. Schröder (ed.), Genetics and mutagenesis of fish, pp. 33-63. Springer, New York (1973).

ANDERS, F., A biologist's view in human cancer. I $m$ : R. Neth and R.C. Gallo (eds.). Modern trends in human leukemia, XIII, pp. 23-45, Springer, Berlin (1989).

Anders, F., Scharth, M., Barnekow, A. and Anders, A., Xiphophorus as an in vivo model for studies on normal and defective control of oncogencs. Advanc. Cancer Res., 42, 191-275 (1984). 
Ellus, R.W. Defeo, D, Maryak, J.M., Young, H.A., Shih, T.Y CHANG, E.H., LOWY, D.R. and SCOLNICK, E.M., Dual evolutionary origin for the rat genomic sequences of Harvey murine sarcoma virus. J. Virology, 36, 408-420 (1980).

FeINBERG, A.P. and Vogelstein, B., A technique for radio labelling DNA-restriction endonuclease fragments to high specific activity. Anal. Biochem., 137, 266-267 (1984).

Filmus, J., Pollack, M.N., Cailleau, R. and Buick, R.W., MDA 468, a human breast-cancer cell line with a high number of epidermalgrowth-factor (EGF) receptors, has an amplified EGF-receptor gene and is growth-inhibited by EGF. Biochem. biophys. Res. Commun, 128, 898-905 (1985).

FRANCKE, U., A gene for Wilms tumour? Nature (Lond.), 343, 692-694 (1990).

Hannig, G., OtTilie, S. and Schartl, M., Conservation of structure and expression of the c-yes and fyn genes in lower vertebrates. Oncogene, 6, 361-369 (1991).

KaLLMAN, K.D. The platyfish Xiphophorus maculatus. In: R.C. King (ed.), Handbook of genetics, 4, pp. 81-132, Plenum, New York (1975). KHANDJIAN, E.W., UV crosslinking of RNA to nylon membranes enhances hybridization signals. Mol. Biol. Rep., 11, 105-115 (1986).

KING, C.R., Kraus, M.H. and Aaronson, S.A., Amplification of a novel verb B-2-related gene in a human mammary carcinoma. Science, 229, 974-976 (1985).

LEHRACH, H., Diamond, D., WOZNEY, J.M. and BOEDTKER, H., RNA molecular-weight determinations by gel electrophoresis under denaturing conditions, a critical re-examination. Biochemistry, 16, 4743-4751 (1977).

Le Meur, M., Glanville, N., Mandel, J.L., Gerlunger, P., PalMITER, $R$. and CHAMBON, $P$., The ovalbumin gene family: hormona control of $\mathrm{X}$ and $\mathrm{Y}$ gene transcription and mRNA accumulation. Cell, 23, 561-571 (1981).

LibermanN, T.A., Nusbaum, H.R., Razon, N., KRIS, R., LaX, R. SOREG, H., WhITTLE, N., WATERfIELD, M.D., ULlRICH, A. and SCHLESSINGER, J., Amplification, enhanced expression and possible rearrangement of EGF-receptor gene in primary human brain tumors of glial origin. Nature (Lond.), 313, 144-147 (1985).

Mäueler, W., Barnekow, A., Eigenbrodt, E., Raulf, F., Falk, H. Telling, A. and ScharTl, M., Different regulation of oncogene expression in tumor and embryonal cells of Xiphophorus. Oncogene, 3 , 113-122 (1988a).

Mäueler, W., Eigenbrodt, E., SChartl, M. and ANders, F. Intermediary metabolism of normal and tumorous tissue of Xiphophorus (Teleostei: Poecilidae). Comp. Biochem. Physiol., 88B, 481-490 (1987).

Mäueler, W., Raulf, F. and Schartl, M., Expression of protooncogenes in embryonic, adult, and transformed tissue of Xiphophorus (Teleostei: Poeciliidae). Oncogene, 2, 421-430 (1988b).

Raulf, F., Mäueler, W., Robertson, S.M. and Schartl, M., Localization of cellular $s r c$ mRNA during development and in the differentiated bipolar neurons of the adult neural retina in Xiphophorus. Oncogene Res., 5, 39-47 (1989).

RIEHL, R., SCHARTL, M. and ANDERS, F., Ultrastructure of malignant melanoma in Xiphophorus. In: J. Bagnara, S.N. Klaus, E. Paul and M. Schartl (eds.), Biological, molecular and clinical aspects of pigmentation, pp. 457-464, Tokyo Press, Tokyo (1985).
Sambrook, J., Fritsch, E.F. and Maniatis, T., Molecular cloning: $a$ laboratory manual, Cold Spring Harbor Laboratory, New York (1988). Sariban, E.T., Mitchell, T. and KaUfE, D., Expression of the c-fms proto-oncogene during human monocytic differentiation. Nature (Lond.), 310, 64-66 (1985).

Schartl, M., Schmidt, C.R., Anders, A. and Barnekow, A. Elevated expression of the cellular src gene in tumors of differing etiologies in Xiphophorus. Int. J. Cancer, 36, 199-207 (1985).

ScharTl, M., Wittbrodt, J., Adam, D., MäUeler, W., RaulF, F. HanNig, G., Robertson, S.M., Telling, A., ANDEXINGer, S. and STORCH, F., Oncogenes and melanoma formation in Xiphophorus. In: J.H. Schröder and M. Schartl (eds.) New trends in ichthyology, Parey, Hamburg (1993) (In press).

Schwab, M., HaAs, J., Abdo, S., Ahuja, M.R., Kollinger, G., ANDERS, A. and ANDERS, F., Genetic basis of the susceptibility for the induction of neoplasms by $N$-methyl- $N$-nitrosourea (MNU) and X-rays in the platyfish/swordtail tumor system. Experientia, 34, 780-782 (1978).

SHERr, C.J., The fms oncogene. Biochim. Biophys Acta, 948, 225-243 (1988)

Sherr, C.J., RetTenmier, C.W., Sacca, R., Roussel, M.F., Look A.T. and STANLEY, E.R., The c-fims proto-oncogene product is related to the receptor for mononuclear phagocyte growth factor. Cell, $\mathbf{4 1}$, 665-676 (1985).

Travis, J., Closing in on melanoma susceptibility gene(s). Science, 258, 1080-1081 (1992).

ULLRICH, A. and SCHLESSINGER, J., Signal transduction by receptors with tyrosine kinase activity. Cell, 61, 203-212 (1990).

Vanbeneden, R.J., Watson, D.K., Chen, T.T. Lautenberger, J.A and PAPAS, T.S., Cellular myc (c-myc) in fish (rainbow trout): its relationship to other vertebrate myc genes and to the transforming genes of the MC 29 family of viruses. Proc. nat. Acad. Sci. (Wash.), 83, 3698-3702 (1986).

VIELKIND, J., VIELKIND, U. and ANDERS, F., Melanotic and amelanotic melanomas in xiphophorine fish. Cancer Res., 31, 868-875 (1971).

Wakamatsu, Y., Oikawa, M., Obika, M., Hirobe, T. and Ozato, K. Fish hereditary melanoma cell lines of different degrees of cell differentiation. Devel. Growth Differ., 26, 503-513 (1984).

WitTBRodT, J., ADAM, D., MALITSChEK, B., MäUeler, W., RAUlF, F., Telling, A., RoberTSON, S.M. and SCHARTL, M., Novel putative receptor tyrosine kinase encoded by the melanoma-inducing $T u$ locus in Xiphophorus. Nature (Lond.), 341, 415-421 (1989).

Wittbrodt, J., Lammers, R., Malitschek, B., Ullrich, A. and SCHARTL, M. The Xmrk receptor tyrosine kinase is activated in malignant melanoma of Xiphophorus. EMBO J., 11, 4239-4246 (1992). Yamamoto, T., Kamata, N., Kawano, H., Shimizu, S., Kuroki, T., TOYOSHIMA, K., RIKIMARU, K., NOMURA, N., ISHIZAKI, R. PASTAN, J., GAMON, S. and SHIMIZU, N., High incidence of amplification of epidermal-growth-factor-receptor gene in human squamous-carcinoma cell lines. Cancer Res., 46, 414-416 (1986).

ZeChel, C., Peters, H., SChleendecker, U. and ANders, F., Expression of genes related to the human erb B, erb A, pdgf and pdgf-r in tumors of different etiology in Xiphophorus. Int. J. Cancer, 52, 66-75 (1992). 